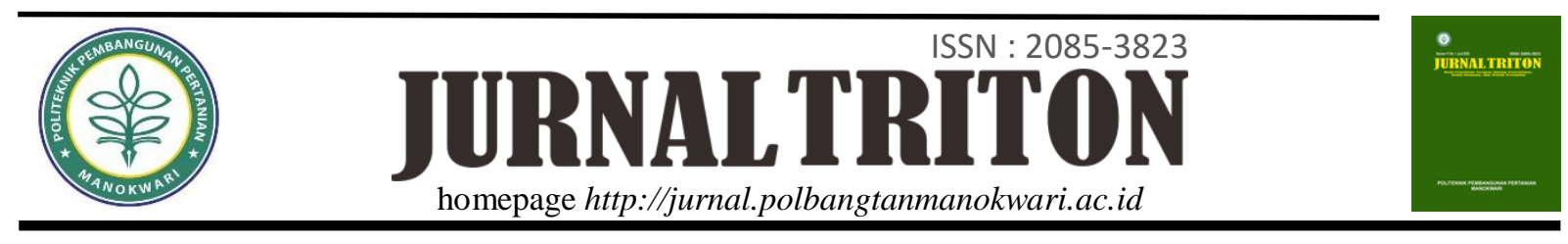

\title{
Akses Teknologi Informasi melalui Media Elektronik pada Petani KRPL
}

Rizki Ardelia ${ }^{1}$, Oeng Anwarudin ${ }^{2}$, Nazaruddin ${ }^{3}$

1,3 Jurusan Penyuluhan Pertanian, Politeknik Pembangunan Pertanian Bogor

${ }^{2}$ Jurusan Penyuluhan Pertanian, Politeknik Pembangunan Pertanian Manokwari

\begin{tabular}{l}
\multicolumn{1}{c}{ ARTIKEL INFO } \\
\hline Sejarah artikel \\
Diterima 02/06/2020 \\
Diterima dalam bentuk revisi 24/06/2020 \\
Diterima dan disetujui 26/06/2020 \\
Tersedia online 30/06/2020 \\
\hline Kata kunci : \\
Media penyuluhan \\
Penyuluhan pertanian \\
Teknologi informasi \\
\hline
\end{tabular}
\begin{abstract}
ABSTRAK
Penggunaan media elektronik dan pendekatan kawasan rumah pangan lestari merupakan gabungan dua metode penyuluhan pertanian yang dianggap efektif untuk mempertahankan kehidupan petani perkotaan di masa pandemi covid-19 saat ini. Penelitian ini bertujuan menganalisis tingkat akses petani dan faktor yang mempengaruhi akses teknologi informasi melalui media elektronik pada petani Kawasan Rumah Pangan Lestari (KRPL) serta merumuskan strategi yang tepat untuk meningkatkan akses teknologi informasi melalui media elektronik pada petani KRPL. Penelitian telah dilakukan di Kelurahan Hadimulyo Barat dan Hadimulyo Timur, Metro Pusat, Kota Metro, Lampung pada April hingga Juni 2020. Sampel penelitian yaitu 46 petani yang tergabung dalam kelompoktani yang telah menerapkan program KRPL. Sampel ditentukan menggunakan quota sampling berdasarkan pada keaktifan anggota kelompok. Peubah penelitian terdiri atas karakteristik petani, dukungan fasilitas teknologi informasi, peranan penyuluh dan akses teknologi informasi. Pengumpulan data primer menggunakan instrument berupa kuesioner. Data diolah menggunakan teknik analisis statistik deskriptif dan regresi berganda serta analisis SWOT. Hasil penelitian mengenai akses teknologi informasi melalui media elektronik pada petani KRPL ada pada kategori tinggi dengan persentase $70,7 \%$. Faktor faktor yang mempengaruhi tingkat akses petani melalui media elektronik yaitu jumlah tanggungan keluarga, dukungan fasilitas akses teknologi informasi serta peranan penyuluh pertanian. Strategi untuk meningkatkan akses petani dapat dilakukan dengan memanfaatkan kekuatan dan peluang yang ada pada kelompoktani serta memanfaatkan peluang yang ada untuk memperbaiki kelemahan. Beberapa upaya yang dapat dilakukan adalah memperkuat peranan penyuluh pertanian dan dukungan fasilitas teknologi informasi seperti media elektronik.
\end{abstract}

(C) 2020 Politeknik Pembangunan Pertanian Manokwari 


\section{ABSTRACT}

Electronic media and house area can be two efective method to increase farmer living in this pandemic. Purpose of this research are analyzing level of farmer access, affecting factor and define strategic to increase electronic technology information access at Sustainable Food House Area (SFHA) farmer. This research held at Central Metro, Metro City, Lampung on April - June 2020. The research sample is 46 farmers who are members of the farmer groups who have implemented the KRPL program. The sample is determined using quota sampling based on the activeness of group members. The research variables consisted of the characteristics of farmers, support of information technology facilities, the role of extension workers and access to information technology. Primary data collection using instruments in the form of questionnaires. Data were

\section{PENDAHULUAN}

Pengembangan teknologi dan inovasi pertanian yang telah dilaksanakan dapat diterapkan untuk meningkatkan produktivitas dan kesejahteraan petani. Hal ini melengkapi dan mengembangkan praktik pertanian modern yang selama ini sudah dijalankan baik pada subsistem hulu maupun hilir. Salah satu pengembangan praktik pertanian modern yang sudah banyak dilakukan oleh masyarakat perkotaan adalah kegiatan Kawasan Rumah Pangan Lestari (KRPL). Program ini merupakan pemanfaatan lahan pekarangan untuk mendukung ketahanan pangan dan kemandirian pangan keluarga yang dipandang sebagai langkah strategis pada kondisi krisis seperti pada saat pandemi covids-19.

Sebagai gambaran pada krisis ekonomi tahun 1998, bidang pertanian di pedesaan tidak terpengaruh oleh krisis ekonomi di Indonesia. Dari awal mula krisis sampai kuartal ketiga tahun 1998, sektor pertanian menunjukkan pertumbuhan $0-1 \%$ melebihi sektor lainnya (NRMP, 1999). Hal tersebut terulang kembali processed using descriptive statistical analysis techniques and multiple regression and SWOT analysis. Result of this reasearch are farmer access at electronic technology information access is high with precentage $70,7 \%$, number of family, technology information access facility and extension roles are affecting factor of this research. Strategies to improve farmers' access can be done by utilizing the strengths and opportunities that exist in farmer groups and taking advantage of existing opportunities to correct weaknesses. Some efforts that can be done are strengthening the role of agricultural extension workers and the support of information technology facilities such as electronic media.

di tahun 2020, dampak corona virus disease 19 (Covid-19) menyebabkan beberapa sektor di Indonesia harus terhenti dan berdampak pada sosial ekonomi masyarakat. Perlunya sinergi dari para petani, penyuluh dan pelaku sektor pertanian lainnya untuk menjadi pahlawan pada masa sulit seperti ini demi mewujudkan kemandirian pangan.

Luas pekarangan yang tersebar di Kecamatan Metro Pusat seluas 157 Ha (BPS Kota Metro, 2019). Petani, penyuluh dan pelaku sektor pertanian lainnya aktif melakukan kegiatan KRPL. Kegiatan tersebut dilaksanakan dengan tidak melupakan protokol kesehatan yang telah ditetapkan pemerintah pusat maupun pemerintah daerah. Penyuluh pertanian tetap melakukan pembinaan kelompok tani dengan memperhatikan physical distancing.

Beberapa kegiatan yang melibatkan banyak orang saat ini mengalami penundaan, namun hal tersebut dapat diatasi dengan memanfaatkan teknologi informasi. Petani tetap dapat melakukan diskusi kelompok melalui daring yang dilakukan melalui whatsapp grup. 
Penyuluh dan beberapa pelaku sektor pertanian lainnya pun turut aktif dengan memberikan materi pertanian pada masa pandemi saat ini melalui aplikasi teleconference zoom meeting dan beberapa aplikasi sederhana lainnnya. Melalui akses teknologi informasi diharapkan petani mengalami peningkatan pengetahuan sehingga dapat memotivasi masyarakat untuk lebih bergairah melaksanakan usahatani terutama pada kegiatan KRPL. Kegiatan ini diharapkan mampu mendorong terciptanya kegiatan-kegiatan produktif serta inovasi baru pada bidang pertanian untuk meningkatkan pendapatan dan kesejahteraan petani. Penelitian bertujuan (1) menganalisis secara deskriptif akses teknologi informasi melalui media elektronik, (2) menganalisis faktor-faktor yang mempengaruhi akses teknologi informasi melalui media elektronik, dan (3) menetapkan strategi untuk meningkatkan akses teknologi informasi melalui media elektronik pada petani KRPL di Kecamatan Metro Pusat, Kota Metro.

\section{METODE}

Penelitian dilaksanakan di Kecamatan Metro Pusat, Kota Metro, Lampung pada Maret sampai dengan Juli 2020. Sampel penelitian sebanyak 46 ditentukan dengan teknik quota sampling berdasarkan pada anggota kelompok wanita tani yang aktif menerapkan kegiatan KRPL. Peubah penelitian terdiri atas karakteristik petani, dukungan fasilitas akses teknologi, peranan penyuluh dan akses petani. Data penelitian diambil menggunakan instrument berupa kuesioner. Instrumen telah melalui uji validitas dan reliabilitas dengan hasil valid dan reliabel.

Data dianalisis menggunakan statistik deskriptif dan inferensial, serta analisis SWOT (Strength/Kekuatan, Weakness/Kelemahan, Opportunity/Peluang) dan Threat/Ancaman). Analisis statistik deskriptif dilakukan dengan mengelompokkan data yaitu membagi jawaban responden yang dikelompokkan dalam empat kategori (1) sangat rendah, (2) rendah, (3) tinggi dan (4) sangat tinggi. Analisis statistik inferensial melalui uji regresi berganda dilakukan untuk menguji faktor-faktor yang mempengaruhi akses teknologi informasi melalui media elektronik. Analisis SWOT dilakukan untuk menyusun strategi peningkatan akses teknologi informasi melalui media elektronik pada petani KRPL.

\section{HASIL DAN PEMBAHASAN}

\section{Karakteristik Responden}

Tabel 1 menunjukkan sebagian besar responden berada pada kategori umur 36 sampai dengan 55 tahun dengan porsi 78,26 persen. Kondisi ini mencerminkan bahwa pelaku KRPL pada umumnya berada pada umur menengah dan lanjut sesuai dengan laporan Liani et al. (2018). Komposisi tersebut juga sesuai dengan komposisi petani saat ini yang didominasi oleh generasi lanjut (Putri et al., 2019). Rendahnya porsi petani muda (10,87\%) mirip dengan laporan Harniat dan Anwarudin (2018) yang menyebutkan sekitar 12 persen sesuai hasil sensus pertanian tahun 2013. 
Tabel 1. Karakteristik Responden Penelitian

\begin{tabular}{|c|c|c|c|c|c|}
\hline No. & Karakteristik & Uraian & Kategori & Jumlah & Persentase $(\%)$ \\
\hline & Umur & $26-35$ & & 5 & 10,87 \\
\hline & & $36-45$ & & 20 & 43,48 \\
\hline & & $46-55$ & & 16 & 34,78 \\
\hline & & $56-65$ & & 5 & 10,87 \\
\hline & & & Total & 46 & 100 \\
\hline \multirow{5}{*}{\multicolumn{2}{|c|}{ 2. Pendidikan }} & PT & & 3 & 6,52 \\
\hline & & SMA & & 36 & 78,26 \\
\hline & & SMP & & 4 & 8,69 \\
\hline & & SD & & 3 & 6,52 \\
\hline & & & Total & 46 & 100 \\
\hline \multirow{5}{*}{\multicolumn{2}{|c|}{ 3. Lama Usaha Tani }} & $>21$ & Sangat Tinggi & 1 & 2,17 \\
\hline & & $15-21$ & Tinggi & 3 & 6,52 \\
\hline & & $8-14$ & Sedang & 5 & 10,87 \\
\hline & & $<7$ & Rendah & 37 & 80,43 \\
\hline & & & Total & 46 & 100 \\
\hline \multirow{5}{*}{\multicolumn{2}{|c|}{ 4. Tanggungan Keluarga }} & $0-1$ & Rendah & 2 & 4,35 \\
\hline & & $2-3$ & Sedang & 25 & 54,35 \\
\hline & & 4 & Tinggi & 16 & 34,78 \\
\hline & & 5 & Sangat Tinggi & 3 & 6,52 \\
\hline & & & Total & 46 & 100 \\
\hline \multirow{5}{*}{\multicolumn{2}{|c|}{ 5. Kepemilikan TI }} & 5 & Sangat Tinggi & 9 & 19,57 \\
\hline & & 4 & Tinggi & 18 & 39,13 \\
\hline & & $2-3$ & Sedang & 18 & 39,13 \\
\hline & & $0-1$ & Rendah & 1 & 2,17 \\
\hline & & & Total & 46 & 100 \\
\hline
\end{tabular}

Jenjang pendidikan yang ditempuh individu dapat mempengaruhi tingkat berpikir dan penalarannya dalam mengambil keputusan. Hasil penelitian yang dilakukan pada petani responden menunjukkan tingkat pendidikan yang tinggi, sebanyak 36 responden atau $78,26 \%$ penelitian memiliki latar belakang pendidikan SMA. Padahal, petani umumnya mayoritas berpendidikan sekolah dasar (SD) (Anwarudin, 2017; Liani et al., 2018; Saputra et al., 2018; Anggini et al., 2019). Hal tersebut menunjukkan bahwa tingkat pendidikan formal petani sudah lebih baik dibandingkan dengan petani pada umumnya sesuai dengan laporan Wardani dan Anwarudin (2018), Nazarudin dan Anwarudin (2019), Anwarudin et al. (2019), Dayat dan Anwarudin (2020) dan Dayat et al. (2020). Keadaan ini dapat dipahami mengingat responden penelitian ini adalah masyarakat perkotaan di Kecamatan Metro Timur, Kota Metro.

Tabel 1 memperlihatkan sebagian besar responden memiliki pengalaman yang rendah yaitu dibawah 7 tahun. Semakin lama pengalaman usahatani maka petani akan memiliki ketrampilan dan pengetahuan yang 
lebih luas mengenai usahatani (Noer et al., 2018). Namun pada praktiknya, petani responden sudah memiliki ketrampilan dan pengetahuan yang luas mengenai kegiatan KRPL yang dilakukannya. Hal tersebut dapat dibuktikan dengan akan diadakannya program pengembangan kegiatan KRPL menjadi kegiatan pertanian terpadu. Ketrampilan dan pengetahuan tersebut diperoleh petani tidak hanya melalui pengalaman usahatani yang dilakukannya saja, melainkan petani turut aktif dalam beberapa kegiatan diklat, pelatihan dan kegiatan lainnya yang menunjang usahataninya. Pengalaman tersebutlah yang menjadi acuan usahatani yang diterapkan pada kegiatan KRPL selanjutnya.

Mayoritas responden memiliki jumlah anggota keluarga 2 sampai 3 orang. Jumlah tanggungan keluarga ini berpengaruh terhadap pengeluaran rumah tangga petani dalam pemenuhan kebutuhan pokoknya. Tanggungan keluarga tersebut menunjukkan komposisi keluarga yang terdiri atas bapak, ibu dengan 1 atau 2 orang anak. Hal ini merupakan keluarga yang ideal sesuai dengan rekomendasi Keluarga
Berencana yaitu 2 orang anak lebih baik. Kondisi tersebut dapat dipahami mengingat responden penelitian ini merupakan masyarakat perkotaan.

\section{Dukungan Fasilitas Akses Teknologi}

Dukungan fasilitas akses teknologi merupakan element sarana prasarana dalam pemenuhan akses teknologi petani baik melalui lingkungan fisik maupun sosial. Mayoritas petani responden menyatakan pendukung akses teknologi informasi melalui media elektronik di Metro Pusat dalam kategori tinggi sebesar $41,3 \%$, sedangkan $58,7 \%$ petani responden lainnya menyatakan hal berbeda seperti pada Tabel 2. Semakin tinggi persentase dukungan fasilitas akses teknologi bermakna bahwa lingkungan fisik dan lingkungan sosial responden memiliki sifat yang semakin kondusif. Dengan demikian diharapkan dapat memotivasi petani dalam berusahatani yang pada akhirnya meningkatkan keinovatifan dan kesadarannya untuk mencari informasi yang dibutuhkan. Penelitian ini mendukung penelitian Tamba (2007).

Tabel 2. Persentase Dukungan Fasilitas Akses Teknologi Informasi melalui Media Elektronik

\begin{tabular}{|c|c|c|c|}
\hline No. & Kategori & Jumlah Responden & Persentase $(\%)$ \\
\hline 1. & Sangat Tinggi & 18 & 39,13 \\
\hline 2. & Tinggi & 19 & 41,3 \\
\hline 3. & Sedang & 9 & 19,56 \\
\hline \multirow[t]{2}{*}{4.} & Rendah & 0 & 0 \\
\hline & Total & 46 & 100 \\
\hline
\end{tabular}

$\begin{array}{lll}\text { Keberadaan } & \text { lingkungan sosial } & \text { kebudayaan baru dibandingkan dengan } \\ \text { responden tergolong modern. Petani tidak } & \text { pertanian zaman dahulu. Munculnya } \\ \text { memiliki pantangan terhadap adat istiadat } & \text { kebudayaan baru ini relatif lebih halus karena } \\ \text { maupun norma agama dan ini termasuk } & \text { penyatuan unsur kebudayaan yang saling }\end{array}$


bertemu untuk kemudian memunculkan kebudayaan baru sebagai hasil penyatuan berbagai unsur budaya. Hal tersebut sejalan dengan penelitian Martono (2012), lingkungan sosial petani yang modern mendukung dalam peningkatan akses teknologi informasi untuk menimbulkan inovasi yang akan berdampak pada peningkatan taraf hidup petani dan memunculkan budaya baru dalam kegiatan pertanian yang bersifat positif.

\section{Peranan Penyuluh}

Penyuluh memiliki peranan penting sebagai ujung tombak serta jembatan antara pemerintah dan petani sebagai pelaku utama sehingga dituntut memiliki pengetahuan, informasi yang memadai untuk petani dan kemampuan untuk akses dan tanggap terhadap perkembangan teknologi (Wijaya et al., 2019). Tabel 3 menunjukkan sebanyak 24 responden memiliki penilaian yang tinggi terhadap peranan penyuluh dalam mempengaruhi akses teknologi informasi melalui media elektronik.

Tabel 3. Persentase Peranan Penyuluh dalam Akses Teknologi Informasi melalui Media Elektronik

\begin{tabular}{clcc}
\hline No. & \multicolumn{1}{c}{ Kategori } & Jumlah Responden & Persentase $(\boldsymbol{\%})$ \\
\hline 1. & Sangat Tinggi & 17 & 36,95 \\
2. & Tinggi & 24 & 52,17 \\
3. & Sedang & 5 & 10,86 \\
4. & Rendah & 0 & 0 \\
\hline & Total & $\mathbf{4 6}$ & $\mathbf{1 0 0}$ \\
\hline
\end{tabular}

Pentingnya peranan penyuluh dalam peningkatan akses teknologi informasi petani melalui media digital untuk memotivasi petani dalam berusahatani yang pada akhirnya akan meningkatkan keinovatifan sangat dibutuhkan. Hal ini dianggap model ideal dalam penyebaran inovasi berbasi teknologi informasi dengan memanfaatkan penyuluh dan kelembagaan lokal dengan beberapa penyempurnaan peranannya masing-masing dan mendukung penelitian yang dilakukan oleh Sumardjo et al., (2012). Peranan penyuluh tertinggi dalam penelitian ini terletak pada parameter motivator, yang berarti penyuluh memiliki peranan untuk memberi dukungan dan semangat kepada kelompoktani agar mau dan mampu meningkatkan akses teknologi informasi melalui media elektronik dalam kegiatan KRPL.

\section{Akses Teknologi Informasi Pertanian}

Akses pelaku utama pembangunan pertanian terhadap berbagai informasi dan inovasi pertanian menjadi isu yang sangat krusial dalam menentukan keberhasilan pembangunan pertanian dan pedesaan (Subejo, 2011). Penelitian yang dilakukan di Kecamatan Metro Pusat menyatakan akses petani yang tinggi terhadap teknologi informasi melalui media elektronik pada kegiatan KRPL. Petani responden sudah melek terhadap teknologi informasi yang saat ini berkembang artinya petani sudah dapat menerima perubahan zaman dan dapat beradaptasi dengan hal ini. Dengan perubahan zaman ini, petani khususnya dapat 
memanfaatkan peluang ini untuk meningkatkan taraf hidupnya. Tabel 4 memperlihatkan sebanyak 28 responden atau $60,86 \%$ memiliki kategori yang tinggi dalam akses teknologi informasi pertanian melalui media elektronik pada kegiatan KRPL.

Tabel 4. Persentase Akses Teknologi Informasi Pertanian melalui Media Elektronik

\begin{tabular}{clcc}
\hline No. & \multicolumn{1}{c}{ Kategori } & Jumlah Responden & Persentase (\%) \\
\hline 1. & Sangat Tinggi & 0 & 0 \\
2. & Tinggi & 28 & 60,86 \\
3. & Sedang & 18 & 39,13 \\
4. & Rendah & 0 & 0 \\
\hline & Total & $\mathbf{4 6}$ & $\mathbf{1 0 0}$ \\
\hline
\end{tabular}

Berdasarkan hasil analisis statistik yang telah dilakukan, tingkat akses teknologi informasi pertanian melalui media elektronik di Kecamatan Metro Pusat termasuk dalam kategori tinggi dengan persentase tingkat akses sebesar $70,7 \%$. Parameter tertinggi terhadap pengukuruan tingkat akses petani melalui media elektronik berada pada parameter kualitas akses teknologi informasi petani dengan persentase penilaian sebesar $74,86 \%$, hal ini menandakan keberadaan dan kemampuan media elektronik dalam menyediakan informasi yang dibutuhkan oleh petani tinggi serta memiliki manfaat yang tinggi dalam proses belajar dalam pengembangan kegiatan KRPL yang dilakukan oleh responden. Informasi yang diperoleh petani dalam kegiatan akses terhadap teknologi informasi pertanian melalui media elektronik dinilai memiliki keakuratan yang tepat terhadap kegiatan KRPL yang dilakukan petani.

Tingkat akses petani melalui media elektronik tinggi, hal tersebut dapat dilihat pada Tabel 5 yang menyatakan akses teknologi informasi petani melalui media elektronik terhadap jenis informasi memiliki persentase sebesar $70,5 \%$ dan termasuk dalam kategori tinggi. Angka ini menunjukkan keragaman jenis informasi yang diakses petani beragam, mayoritas petani mengakses informasi budidaya melalui media elektronik yang dimilikinya. Teknik budidaya yang diakses meliputi teknik pengolahan lahan, pengendalian hama, pengairan, pemupukkan dan penyiangan. Hal tersebut berbeda dengan temuan Anwarudin dan Dayat (2019) yaitu akses petani terkait pertanian yang sering tampil diantaranya adalah harga produk dan pemasaran.

Tabel 5. Persentase Akses Teknologi Informasi Berdasarkan Parameter

\begin{tabular}{clc}
\hline No. & \multicolumn{1}{c}{ Parameter } & Persentase (\%) \\
\hline 1. & Sumber informasi & 66,44 \\
2. & Intensitas Akses & 65,47 \\
3. & Jenis Informasi & 70,50 \\
4. & Kualitas Akses & 74,86 \\
\hline
\end{tabular}


Adapun jenis informasi yang memiliki intensitas tinggi terletak pada teknik budidaya dengan persentase akses sebesar 75,06\% informasi teknik budidaya yang diakses dengan intensitas tinggi mengenai pengolahan lahan dan pemupukkan. Jenis informasi yang diakses pada saat pengolahan lahan yaitu mengenai pergiliran tanaman/rotasi tanaman beserta kalender tanam yang direkomendasikan dalam kegiatan KRPL untuk memberikan hasil yang maksimal. Kesadaran pentingnya informasi mengenai budidaya tersebut memberikan hasil yang memuaskan terhadap kegiatan KRPL yang dilakukan petani responden. Jenis informasi lain yang diakses petani melalui media elektronik dapat dilihat pada Tabel 6.

Tabel 6. Persentase Akses Petani Berdasarkan Jenis Informasi

\begin{tabular}{clc}
\hline No & \multicolumn{1}{c}{ Parameter } & Persentase (\%) \\
\hline 1. & Penyediaan Saprodi & 74,22 \\
2. & Teknik Budidaya & 75,06 \\
3. & Teknik Panen dan Pasca Panen & 51,61 \\
4. & Informasi Pemasaran & 59,76 \\
\hline
\end{tabular}

Faktor yang Mempengaruhi Akses

Teknologi Informasi melalui Media

\section{Elektronik pada Petani KRPL}

Variabel dependen pada penelitian ini adalah tingkat akses teknologi informasi, sedangkan variabel independen meliputi karakteristik responden, dukungan akses dan peranan penyuluh. Hasil analisis regresi berganda dapat dilihat pada Tabel 7 .

Tabel 7. Hasil Analisis Statistik Regresi Berganda

\begin{tabular}{lccc}
\hline \multicolumn{1}{c}{ Variabel } & Nilai & Sign. & Keterangan \\
\hline $\mathrm{R}^{2}$ & 0,514 & & \\
Konstanta & 43,006 & 0,000 & Signfikan \\
Umur $\left(\mathrm{X}_{1.1}\right)$ & 1,408 & 0,286 & Tidak Signifikan \\
Pendidikan $\left(\mathrm{X}_{1.2}\right)$ & 1,902 & 0,285 & Tidak Signifikan \\
Lama Usahatani $\left(\mathrm{X}_{1.3}\right)$ & $-0,575$ & 0,751 & Tidak Signifikan \\
Jumlah Tanggungan Keluarga $\left(\mathrm{X}_{1.4}\right)$ & 3,451 & 0,024 & Signifikan \\
Jumlah Teknologi Informasi $\left(\mathrm{X}_{1.5}\right)$ & $-0,478$ & 0,744 & Tidak Signifikan \\
Dukungan fasilitas Akses $\left(\mathrm{X}_{2}\right)$ & 0,981 & 0,001 & Signifikan \\
Peranan Penyuluh $\left(\mathrm{X}_{3}\right)$ & 1,312 & 0,000 & Signifikan \\
\hline
\end{tabular}

Hasil analisis statistik pengujian faktor faktor yang mempengaruhi tingkat akses teknologi informasi pertanian melalui media elektronik pada petani KRPL menghasilkan persamaan sebagai berikut:

$Y=43,006+3,451 X 1.4+0,981 X 2+1,312$ X3
Persamaan tersebut digunakan untuk meramalkan besarnya nilai variabel independen terhadap akses teknologi informasi pertanian melalui media elektronik pada petani KRPL. Hasil pengujian analisis regresi linier berganda diperoleh nilai konstanta sebesar 43,006, dan 1,312 untuk variabel peranan penyuluh. Makna 
dari persamaan ini yaitu setiap kenaikan variabel X3 sebanyak 1 poin dan variabel lainnya konstan maka nilai variabel $\mathrm{Y}$ akan meningkat sebanyak 1,312 poin. Hal tersebut berlaku pada variabel lainnya.

Hasil analisis regresi linier berganda menunjukkan jumlah tanggungan keluarga memiliki nilai koefisien sebesar 3,451 dengan nilai signifikasi $0,024<0,05$. Ini berarti semakin besar jumlah anggota keluarga dalam rumahtangga tani maka semakin rendah tingkat akses teknologi informasi petani melalui media elektronik, hal ini selaras dengan penelitian Awal (2018). Faktor selanjutnya yang berpengaruh pada akses teknologi informasi yaitu dukungan fasilitas akses teknologi yang meliputi lingkungan fisik dan lingkungan sosial termasuk nilai budaya setempat, dukungan keluarga dan tokoh masyarakat serta interaksi sosial petani dengan masyarakat dengan nilai koefisien 0,981 dan nilai signifikasi 0,001 < 0,05 . Hal ini berarti semakin tinggi persentase sarana prasarana akses maka semakin tinggi ketersediaan sarana informasi berbasis teknologi informasi yang ada akan mendorong pada semakin tingginya tingkat perilaku petani dalam meningkatkan keinovatifan dan kesadarannya untuk mencari informasi yang dibutuhkan.

Faktor lain yang memiliki tingkat signifikan dalam penelitian ini yaitu peranan penyuluh. Tabel 7. menyatakan taraf signifikasi pada peranan penyuluh yaitu $0,000<0,005$. Tingkat signifikasi pada variabel ini merupakan tingkat signifikasi yang paling berpengaruh terhadap variabel dependen. Pada praktiknya, penyuluh pertanian di Kecamatan Metro Pusat mendorong petani untuk melakukan akses teknologi informasi melalui pendekatan media elektronik khususnya pada telepon seluler untuk menyebarkan informasi pertanian serta memantau kegiatan KRPL yang dilakukan oleh kelompoktani. Dengan menggunakan aplikasi whatsapp petani dan penyuluh tergabung didalam percakapan grup yang menghubungkan kedua belah pihak melalui aplikasi tersebut, dengan adanya percakapan grup tersebut penyuluh pertanian dapat menyebarkan dan memantau kegiatan usahatani yang dilakukan oleh kelompoktani. Pendekatan yang dilakukan penyuluh dengan menggunakan media elektronik melalui aplikasi whatsapp termasuk dalam kategori sukses karena petani dan penyuluh turut aktif dalam melakukan komunikasi terutama pada bidang pertanian, petani kerap kali melakukan konsultasi melalui media elektronik mengenai permasalahan pada kegiatan KRPL yang dilakukan. Hal tersebut selaras dengan penelitian yang dilakukan oleh Pradiana et al. (2020) yang mengemukakan bahwa semua bentuk pendekatan penyuluhan pertanian akan berhasil bila dilandasi dengan kelompoktani yang kuat.

\section{Strategi Peningkatan Akses Teknologi Informasi melalui Media Elektronik pada Kegiatan KRPL}

Penyusunan strategi dilakukan dengan menganalisis faktor yang mempengaruhi variabel dependen penelitian yang selanjutnya dilakukan perencanaan strategis untuk mengevaluasi kekuatan, kelemahan, peluang dan ancaman dalam kegiatan akses teknologi informasi petani melalui media elektronik pada kegiatan KRPL. Tabel 8 merupakan 
perencanaan strategis yang dilakukan dalam upaya peningkatan akses teknologi informasi petani melalui media elektronik pada kegiatan KRPL.

Tabel 8. Matriks SWOT Strategi Peningkatan Akses Teknologi Informasi melalui Media Elektronik

\begin{tabular}{|c|c|c|}
\hline IFAS & $\begin{array}{c}\text { Strength } \\
\text { ( Kekuatan ) }\end{array}$ & $\begin{array}{c}\text { Weakness } \\
\text { ( Kelemahan ) }\end{array}$ \\
\hline EFAS & \begin{tabular}{|l} 
1. \\
Penyuluh pertanian dan petani \\
berperanan aktif serta saling \\
bersinergi
\end{tabular} & $\begin{array}{l}\text { 1. Sarana dan prasarana akses } \\
\text { yang berbeda dari tiap petani } \\
\text { 2. Kurangnya intensitas akses } \\
\text { petani dalam melakukan } \\
\text { akses informasi pertanian }\end{array}$ \\
\hline $\begin{array}{c}\text { Opportunity } \\
\text { ( Peluang ) }\end{array}$ & Strategi S-O & Strategi W-O \\
\hline 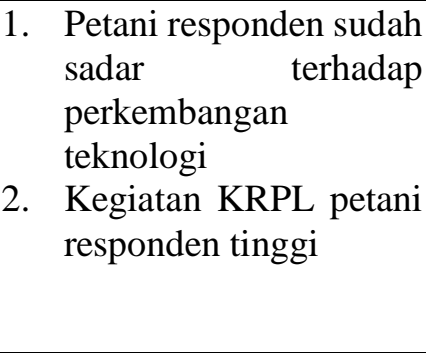 & 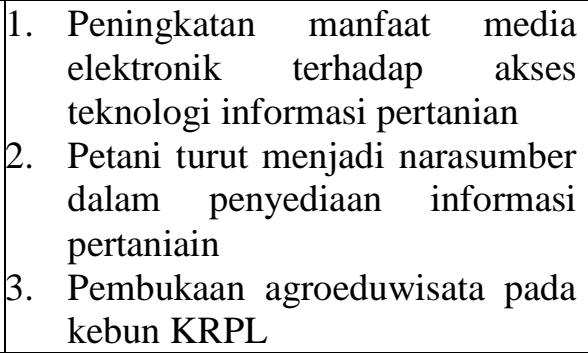 & \begin{tabular}{|lr} 
1. & $\begin{array}{l}\text { Pengajuan bantuan } \\
\text { prasarana }\end{array}$ \\
kelompoktani & akses \\
2. & $\begin{array}{l}\text { Pengembangan } \\
\text { KRPL }\end{array}$
\end{tabular} \\
\hline $\begin{array}{c}\text { Threats } \\
\text { (Ancaman) }\end{array}$ & Strategi S-T & Strategi W-T \\
\hline 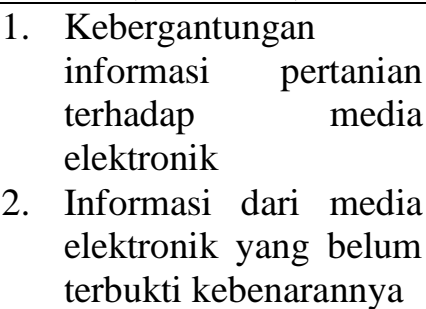 & $\begin{array}{ll}\text { 1. } & \text { Akses informasi melalu beberapa } \\
\text { literasi }\end{array}$ & 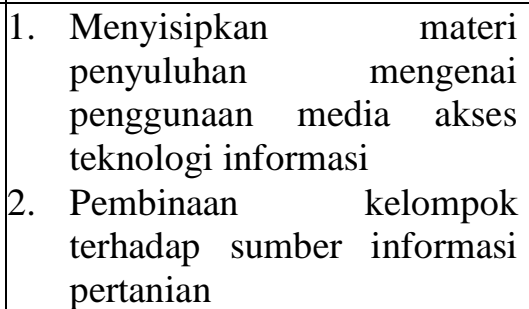 \\
\hline
\end{tabular}

Setelah dilakukan perencanaan strategis melalui matriks, maka selanjutnya dilakukan analisis dan penilaian variabel terhadap strategi yang telah direncakan. Hasil analisis dan penilaian terhadap variabel terpenting selanjutnya akan menghasilkan pemeringkatan strategi yang dianggap mampu meningkatkan akses petani terhadap teknologi informasi melalui media elektronik. Adapun hasil pemeringkatan strategi tersebut yaitu :
1. Strategi $\mathrm{S}-\mathrm{O}$
$: 2,28+2,16=4,44$
2. Strategi $S-T$
$: 2,28+1,14=3,42$

3. Strategi $\mathrm{W}-\mathrm{O}=2,82$

4. Strategi $\mathrm{W}-\mathrm{T} \quad: 0,66+1,14=1,8$

Strategi pertama yang mampu meningkatkan akses petani yaitu dengan memanfaatkan kekuatan dan peluang yang ada pada kelompoktani. Upaya yang dapat dilakukan dengan memaksimalkan pemanfaatan media elektronik petani untuk meningkatkan akses teknologi informasi pertanian Hal ini dapat dilakukan dengan pemanfaatan media online seperti whatsapp group dan sejenisnya untuk saling berdiskusi 
antara petani dan penyuluh serta beberapa stakeholder pertanian lainnya. Selain aktif sebagai pencari informasi, petani juga turut serta untuk menjadi narasumber dalam penyediaan informasi pertanian melalui media elektronik.

Strategi lain yang digunakan untuk meningkatkan akses teknologi informasi melalu media elektronik dalam kegiatan KRPL yaitu dapat dilakukan dengan memanfaatkan peluang yang ada untuk memperbaiki kelemahan yang dimiliki oleh responden. Hal tersebut dapat dilakukan dengan pengajuan bantuan kepada Dinas Pertanian terkait pengadaan sarana prasarana akses kelompoktani melalui media elektronik. Bantuan tersebut dapat menjadi stimulus petani untuk meningkatkan akses teknologi informasi melalui media elektronik. Bantuan tersebut dapat berupa pengadaan oprasional seperangkat alat komputer melalui program jaringan komunikasi penyuluhan pedesaan (JARKOMLUHDES) yang selanjutnya dalam kegiatan tersebut adanya teleconference dengan beberapa stakeholder pertanian, tentu saja hal tersebut dapat memberi motivasi dan semangat baru bagi petani dalam mengakses teknologi informasi pertanian melalui media elektronik.

Pengembangan kegiatan KRPL yang selanjutnya akan dilakukan pada kelompoktani Brayat Hati Makmur dapat juga dijadikan strategi dalam peningkatan akses teknologi informasi pertanian melalui media elektronik. Pengembangan dalam kegiatan KRPL yang akan dilakukan berupa kegiatan pertanian terpadu. Kegiatan dengan menggabungkan antara pertanian, perikanan dan peternakan ini tergolong baru bagi para petani dalam kelompoktani Brayat Hati Makmur. Dengan diadakannya kegiatan yang tergolong baru ini diharapkan mampu memotivasi petani dalam melakukan kegiatan usahatani dan secara tidak langsung dapat membuat petani merasa penasaran terhadap kegiatan ini hingga akhirnya melakukan akses informasi mengenai pertanian terpadu melalui smartphone yang dimilikinya.

\section{KESIMPULAN DAN SARAN}

Tingkat akses teknologi informasi melalui media elektronik pada petani KRPL di Kecamatan Metro Timur, Kota Metro secara keseluruhan termasuk dalam kategori tinggi dengan persentase 70,7\%. Faktor faktor yang mempengaruhi tingkat akses petani melalui media elektronik yaitu jumlah tanggungan keluarga, pendukung akses teknologi informasi serta peranan penyuluh. Strategi yang disusun untuk melakukan peningkatan akses petani dapat dilakukan dengan memanfaatkan kekuatan dan peluang yang ada pada kelompoktani serta memanfaatkan peluang yang ada untuk memperbaiki kelemahan. Beberapa upaya yang dapat dilakukan adalah memperkuat peranan penyuluh pertanian dan dukungan fasilitas teknologi informasi seperti media elektronik. Petani dapat meningkatkan pemanfaatan media online seperti whatsapp group dan sejenisnya untuk saling berdiskusi antara petani dan penyuluh serta beberapa stakeholder 
pertanian lainnya. Petani tidak hanya aktif sebagai pencari informasi tetapi dapat menjadi sumber informasi, pengajuan sarana dan prasarana akses kelompok ke institusi terkait serta melakukan pengembangan kegiatan KRPL.

\section{DAFTAR PUSTAKA}

Hartono, R., \& Anwarudin, O. (2019). Perilaku Petani Dalam Pemanfaatan Limbah Sayuran Sebagai Pupuk Bokashi Pada Tanaman Sawi Putih. Jurnal Triton: Pertanian, 10(1), 99-115.

Anwarudin O, Dayat D. (2019). The effect of farmer participation in agricultural extension on agribusiness sustainability in Bogor, Indonesia. International Journal of Multicultural and Multireligious Understanding (IJMMU), 6(3), 1061-1072.

Anwarudin O, Sumardjo, Satria A, Fatchiya A. (2019). Factors influencing the entrepreneurial capacity of young farmers for farmer succession. International Journal of Innovative Technology and Exploring Engineering (IJITEE), 9(1), 1008-1014.

Awal A. (2018). Pengaruh pendapatan dan jumlah tanggungan keluarga petani padi terhadap tingkat pendidikan anak desa di Desa Pattalasang, Kabupaten Gowa. UIN Alauddin Makassar.

Badan Pusat Statistik (BPS) Kota Metro. (2019). Kecamatan metro pusat dalam angka. Kota Metro, Lampung.

Dayat D, Anwarudin O. (2020). The effect of entrepreneurship capacity on sustainability of young farmers agribusiness. Journal of the Social Sciences, 23(1), 123-134.

Dayat D, Anwarudin O. Makhmudi M. (2020). Regeneration of farmers through rural youth participation in chili agribusiness. International Journal of Scientific and Technology Research (IJSTR), 9(3), 1201-1206.
Harniati H, Anwarudin O. (2018). The interest and action of young agricultural entrepreneur on agribusiness in Cianjur Regency, West Java. Jurnal Penyuluhan, 14(2), 189-198.

Liani F, Sulistyowati D, Anwarudin O. (2018). Perspektif gender dalam partisipasi petani pada Kawasan Rumah Pangan Lestari (KRPL) tanaman sayuran di Kecamatan Kersamanah Kabupaten Garut Provinsi Jawa Barat. Jurnal Penyuluhan Pertanian, 13(1), 21-32.

Martono N. (2012). Sosiologi Perubahan Sosial; prespektif klasik, modern, postmodern dan postkolonial. Jakarta: PT. Raja Grafindo Persada.

Natural Resources Management Project (NRMP). (1999). Analysis of natural resource impacts of Indonesia's financial crisis. Seminar Stury Commissioned, Deputy V of BAPPENAS.

Nazaruddin N, Anwarudin O. (2019). Pengaruh penguatan kelompok tani terhadap partisipasi dan motivasi pemuda tani pada usaha pertanian di Leuwiliang, Bogor. Jurnal Agribisnis Terpadu, 12 (1), 1-14.

Noer SD, Zakaria WA, Murniati K. (2018). Analysis of production efficiency of upland rice farming in Sidomulyo Subdistrict South Lampung Regency. Jurnal Ilmu Ilmu Agribisnis, 6(1), 19.

Pradiana W, Anwrudin O, Maryani A. (2020). Determining factors of the development of agricultural extension office as a knot for coordinating agricultural development. International Journal of Scientific and Technology Research (IJSTR), 9(3), 3766-3773.

Putri CA, Anwarudin O, Sulistyowati D. (2019). Partisipasi petani dalam kegiatan penyuluhan dan adopsi pemupukan padi sawah di Kecamatan Kersamanah Kabupaten Garut. Jurnal Agribisnis Terpadu, 12(1), 103-119.

Saputra C, Anwarudin O, Sulistyowati D. (2018). Persepsi dan adopsi pengendalian hama terpadu lalat buah pada tanaman mangga di Kecamatan Greged Kabupaten Cirebon Provinsi 
Jawa Barat. Jurnal Penyuluhan

Pertanian, 46-60.

Subejo. (2011). Babak baru penyuluhan pertanian dan pedesaan. Jurnal Ilmu Pertanian, 7(1), 61-70.

Sumardjo, Mulyandari RSH, Prawiranegara D, Darmawan L. (2012). Dissemination of agricultural innovation system based on information technology to increase the vegetable farmer empowerment. Prosiding Seminar Hasil Penelitian IPB 2012.

Tamba M. (2007). Thee need of agricultural information and its accessbility for vegetables farmers: developing agricultural information provision model in order to empowerment farmes in West Java Province. Repository IPB Sekolah Pascasarjana.

Wardani, Anwarudin O. (2018). Peran penyuluh terhadap penguatan kelompok tani dan regenerasi petani di Kabupaten Bogor, Jawa Barat. Jurnal Tabaro Agriculture Science, 2(1), 191200.

Wijaya AS, Sarwoprasodjo S, Febrina D. (2019). Cyber extension: use of media and information search strategy in the agriculture of Agricultural Bogor District. Jurnal Komunikasi Pembangunan, 17(2), 117-121. 